\title{
The Supreme Court of Appeal and the handing over of the bride in customary marriages
}

\author{
Siyabonga Sibisi \\ LLB LLM (UKZN) \\ Lecturer, School of Law, University of KwaZulu-Natal, Howard College Campus
}

\begin{abstract}
SUMMARY
While there is unanimity that the mere payment of ilobolo (or part thereof) does not conclude a customary marriage, recent decisions of the SCA indirectly reverse this. Ilobolo must be accompanied by the integration of the bride into her new family in order to conclude a customary marriage. The integration comprises many events - depending on the ethnic group. These events include the handing over of the bride, ukumekeza (Swati). In Moropane $v$ Southon, the SCA held that the handing over of the bride was an indispensable aspect of the integration of the bride. In Mbungela $v$ Mkabi and Tsambo $v$ Sengadi the SCA backtracked on its earlier decision, arguably without any clear principles. This article argues that these decisions of the SCA on customary marriages create uncertainty regarding the conclusion of customary marriages.
\end{abstract}

\section{Introduction}

In the midst of many things that one may say about recent decisions of the Supreme Court of Appeal (hereafter SCA) on customary marriages, one sticks out. If anything, the recent decisions from the second-highest court in the land drive the idea that the living requirements for concluding customary marriages are uncertain and confusing. ${ }^{1}$ The requirements for a customary marriage appear in $s 3(1)^{2}$ of the Recognition of Customary Marriages Act (hereafter the Recognition Act). ${ }^{3}$ Despite appearing clear and unambiguous, s 3(1)(b) of the Recognition Act is the subject of the bulk of the litigation on customary marriages. ${ }^{4}$ This provision, though formal, also seeks to vindicate the importance of

1 Ntlama "The centrality of customary law in the judicial resolution of disputes that emanate from it" 2019 Obiter 202208.

2 3(1) For a customary marriage entered into after the commencement of this Act to be valid the prospective spouses -

(i) must both be above the age of 18 years; and

(ii) must both consent to be married to each other under customary law: and

(iii) the marriage must be negotiated and entered into or celebrated in accordance with customary law.

3 Recognition of Customary Marriages Act 120 of 1998.

4 Osman "The recognition of Customary Marriages Amendment Bill: Much ado about nothing? 2020 SALJ 389400 points out that this provision is open-ended and thus it is the cause of a plethora of litigation in that courts are often called to determine the validity of a marriage. 
living customary law. ${ }^{5}$ In Tsambo $v$ Sengadi, ${ }^{6}$ with reference to its decision in Ngwenyama $v$ Mayelane, ${ }^{7}$ the SCA briefly observed that "the legislature purposefully defers to the living customary law". 8 Viewed this way, s 3(1)(b) of the Recognition Act is a mandate on courts to ascertain the present customs of a particular group and apply them when applicable. ${ }^{9}$ It is submitted that in every customary marriage matter, the courts are called upon to confirm the group(s) to which the parties belong and ascertain the living law of that particular group and apply it. ${ }^{10}$ The ways in which a court may ascertain living law will be discussed below.

The purpose of this article is to critically analyse key decisions of the SCA on customary marriages. These decisions are Moropane $v$ Southon, ${ }^{11}$ Mbungela $v$ Mkabi, ${ }^{12}$ and Tsambo $v$ Sengadi. In general, it is submitted that the SCA has not articulated itself with sufficient clarity on the requirements of customary marriages; in particular, the question of whether the physical handing over of the bride is mandatory and the form that the handing over should take has, arguably, not been put to rest. ${ }^{13}$ It is argued that through the decision in Tsambo $v$ Sengadi, where the bride was not physically handed over; the court may have added credence to the false notion that mere finalisation of the ilobolo negotiations concludes a customary marriage. ${ }^{14}$ This flies in the face of decisions that were decided to the contrary and thus dispelling this false

5 In Mbungela $v$ Mkabi 2020 (1) SA 41 (SCA); [2020] 1 All SA 42 (SCA) para 17 and ND V MM unreported case number 18404/2018 SGJ (12 May 2020) para 28, the court accepted that $\mathrm{s} 3(1)$ (b) was left open-ended to allow communities to give meaning to it in accordance with their lived experiences.

6 Tsambo $v$ Sengadi unreported case number 244/19 SCA (30 April 2020).

$7 \quad$ Ngwenyama v Mayelane 2012 (4) SA 527 (SCA); 2012 (10) BCLR 1071 (SCA); [2012] (3) All SA 408 (SCA) para 23.

$8 \quad$ Tsambo $v$ Sengadi (SCA) supra, para 15.

9 An example of the court doing this appears in Miya $v$ Mnqayane unreported case number 3342/2018 FSB (3 February 2020) para 2, where the court interposes "I pause to mention that the applicant is a Sotho woman and the first respondent hails from a Xhosa family."

10 Mlamla $v$ Rubushe unreported case number 6254/2018 ECM (29 October 2019) para 29

11 Moropane $v$ Southon unreported case number 755/2012 SCA (29 May 2014).

12 Mbungela $v$ Mkabi supra.

13 Interestingly, in $N D \vee M M$ supra, para 34, De Villiers AJ was alive to issues such as this. However, the judge also points out that the problem may lie in the adversarial nature of court proceedings. He states that in this system, it is up to each party to prove his case according to his means and ability: In defence of judges, I do not believe that judges are unwilling to investigate the purpose of a practice, or whether a practice is observed out of a sense of obligation, or merely as a social practice or habit. In an adversarial system, the line between adjudicating the case presented for determination, and entering the arena, must be respected. In addition, parties present their cases within their means, as they identify the issues, and often they can ill-afford a case that snowballs into something much bigger than anticipated.

14 Manthwa "Lobolo, Consent as requirements for the validity of a customary marriage and the proprietary consequences of a customary marriage: $N v D$ (2011/3726) [2016] ZAGPJHC 163”2017 Obiter 438442. 
notion. ${ }^{15}$ One of these decisions is its own decision in Moropane $v$ Southon. To exacerbate the matter, the SCA did not reject these decisions or Moropane $v$ Southon.

In this article, it will also be argued that in Tsambo $v$ Sengadi the court a quo erred in its duty in terms of s 3(1)(b) of the Recognition Act in at least two respects: it did not confirm the group into which the parties belonged, and, because of this omission, it did not ascertain the applicable living law. ${ }^{16}$ Instead, the court introduced concepts such as "symbolic handing over" 17 and went as far as declaring the practice of the handing over of the bride as being unconstitutional. ${ }^{18}$ On appeal, the SCA held, correctly, that the latter aspect of the decision was unnecessary, as it was not at issue. ${ }^{19}$ It is submitted that while the SCA did correct what it thought had gone wrong in the court a quo, it also created some uncertainties that are discussed below.

This article will start with a brief overview of the chosen SCA decisions. It will then analyse these decisions by highlighting certain aspects. These aspects include the consideration of the significance of the physical handing over of the bride. It will show that precedent indicates that the physical handing over of the bride is an integral part of a customary marriage. The question of whether this handing over may be waived is also considered. This article will also look at other aspects that, due to their impact of the SCA jurisprudence on customary marriages, should be studied further. These are the issue of terminology in customary law, the intentions of the parties as opposed to the family groups. Lastly, it will devote itself to a discussion of the uncertainty that has been created by the SCA and then draw a conclusion.

\section{A brief overview of the salient cases of the SCA}

As noted above, this article relies on three salient decisions of the SCA to draw attention to the inconsistency and legal uncertainty. It must be indicated that the selected decisions are not the only decisions of the SCA on customary marriages. They are also not the first decisions to raise issues on customary marriages in general. The case in point is Ngwenyama $v$ Mayelane where the SCA had to decide the effect of the absence of consent of the first wife on Tsonga customary marriages and

15 Motsoatsoa $v$ Roro 2011 (2) All SA 324 (GSJ) para 18 and Meage $v$ Road Accident Fund unreported case number 1809/16 GNP (26 July 2019) para 61, are examples of such decisions.

16 In $N D v M M$ supra, para 5, the court stressed that the community to which the parties belong is the proper source of law and that the court must verify the origins of the litigants before it. In this case, the law of eSwatini was applicable, as ilobolo negotiations and the alleged marriage had taken place there. The court also had to consider the issue of jurisdiction.

17 Sengadi $v$ Tsambo [2019] 1 All SA 569 (GJ) para 19. Also reported as and LS v RL 2019 (4) SA 50 (GJ).

18 Sengadiv Tsambo supra, para 36.

19 Tsambo $v$ Sengadi supra, para 31-33. 
the consequences of failure to comply with s 7(6) of the Recognition Act. S 7(6) of the Recognition Act requires a prior court approved contract if a man wishes to enter into a subsequent customary marriage. ${ }^{20}$ Unlike the salient decisions, Ngwenyana $v$ Mayelane is, arguably, an example of a good judgment because it provided more answers than questions. This is especially true if the issue of the consent of the first wife as a requirement for Tsonga subsequent marriages is considered. While academics agree that this decision applies to Tsonga polygamous customary marriages, it is foreseeable that courts will apply it should a similar matter arise within another ethnic group. ${ }^{21}$

Moropane $v$ Southon precedes the three salient decisions. In this decision, the SCA had to decide whether a valid customary marriage existed. On 17 April 2002, the appellant (husband) sent his emissaries to the home of the respondent (wife). An amount of R6 000 was paid to the respondent's family. The purpose of this payment was in dispute. ${ }^{22}$ The appellant argued that it was go pula molomo or go kokota (literally means the mouth opener or knocking on the door ${ }^{23}$ and, on the other hand, the respondent argued that it was ilobolo. ${ }^{24}$ The payment was followed by the appellant's family handing gifts to the respondent's family. In return, the respondent's family offered a sheep, which was slaughtered and shared between the two families. ${ }^{25}$ The respondent was then draped 26 in a blanket and the elders in her family counselled (go laiwa) her regarding what was expected of her in the appellant's family. ${ }^{27}$ This was followed by a celebration. 28

On request by the appellant's emissaries, the respondent was transported to the appellant's family where the latter's sisters welcomed and counselled her. Celebrations then ensued. ${ }^{29}$ These events are captured in photographs which were admitted to evidence. ${ }^{30}$ The court a quo found that the customary marriage was valid. On appeal, the SCA confirmed that the marriage was valid as all the requirements of a customary marriage were met. The SCA also found that according to customary law in general, and BaPedi included, the handing over of the

20 It must be added that in Ngwenyama $v$ Mayelane, the SCA held that failure to obtain a court approved contract in terms of s 7(6) of the Recognition Act does not invalidate a marriage.

21 See Mwambene "The essence vindicated? Courts and customary marriages in South Africa" 2017 AHRLJ 35.

22 Moropane $v$ Southon supra, para 2.

23 Moropane $v$ Southon supra, para 2.

24 Moropane $v$ Southon supra, para 6.

25 Moropane $v$ Southon supra, para 8.

26 The reason for this is that according to BaPedi culture, it is taboo for a new bride to be seen by her in-laws. see Moropane $v$ Southon supra, para 9.

27 Moropane $v$ Southon supra, para 9-10.

28 Moropane $v$ Southon supra, para 9-10.

29 Moropane $v$ Southon supra, para 11.

30 Moropane $v$ Southon supra, para 9. 
bride is the most crucial aspect of a marriage. The bride is integrated into her new family. ${ }^{31}$

In Mbungela $v$ Mkabi, the respondent sent his emissaries to the home of the deceased (bride). The purpose was to ask for the deceased's hand in marriage in terms of custom. ${ }^{32}$ On the day of the negotiations, an agreement regarding ilobolo was reached. This was followed by partial delivery of ilobolo and the exchange of gifts between the families. ${ }^{33}$ The deceased was not physically handed over to the respondent's family; instead, she remained at her home and followed the respondent a week later. ${ }^{34}$ When the deceased died, her family denied that she and the respondent were married. The court a quo had to determine whether a valid customary marriage was validly entered into. The appellant (the deceased's daughter) argued that there was no customary marriage as the deceased was not handed over to the respondent's family. ${ }^{35}$ On the other hand, the respondent argued that he, a Swati, ${ }^{36}$ was not familiar with the custom of the deceased (the Shangaans) ${ }^{37}$ and he was not informed that the handing over of the deceased had to follow ilobolo negotiations. The court a quo found that the marriage was valid and that the handing over of the bride had been waived by the parties. On appeal, the SCA found that there was overwhelming evidence that the families considered that couple as husband and wife. The SCA seems to have drawn this conclusion from the fact that the deceased family referred to the respondent as the deceased's husband. ${ }^{38}$ The SCA also relied on the fact that the families attended each other's funerals. ${ }^{39}$ This, according to the SCA, leads to the conclusion that the handing over of the bride had been waived. ${ }^{40}$

Tsambo $v$ Sengadi was an appeal following the decision of the High Court in Johannesburg. The decision followed the sad and untimely death of the successful rapper Jabulani Tsambo (also known as HHP). The deceased and the respondent (applicant in the court a quo) met and started dating at the University of the Witwatersrand in 2009. ${ }^{41}$ The parties started cohabiting not long thereafter. A couple of years into the relationship, while the couple was on vacation in Amsterdam, the

31 Moropane $v$ Southon supra, para 40.

32 Mbungela $v$ Mkabi supra, para 5.

33 Mbungela $v$ Mkabi supra, para 5. The said gifts included a man's suit, shirt, tie, socks and a pair of shoes for the deceased's male guardian. It also included a woman's suit for the deceased's mother, a blanket, a headscarf, two snuff boxes, brandy, whisky, a case of beers and a case of soft drinks.

34 Mbungela $v$ Mkabi supra, para 6.

35 Mbungela $v$ Mkabi supra, para 14.

36 Mbungela $v$ Mkabi supra, para 7.

37 Mbungela $v$ Mkabi supra, para 7.

38 Mbungela $v$ Mkabi supra, para 22.

39 Mbungela $v$ Mkabi supra, para 22.

40 Mbungela $v$ Mkabi para 26.

41 Sengadi $v$ Tsambo supra, para 4. For the sake of clarity, that the parties met at the Witwatersrand University does not appear in the judgment of the court $a$ quo. The author relied on the various online newspaper articles for this information. 
deceased proposed marriage to the respondent on 6 November 2015 to which the respondent agreed. ${ }^{42}$ In January of 2016, the appellant (respondent in the court a quo and the deceased's father) dispatched a letter to the respondent's family. ${ }^{43}$ The purpose of the letter was "to discuss the union of their son and her [their] daughter". ${ }^{4}$

The families met at the respondent's home on 28 February 2016 and ilobolo was set at R45 000. The deceased paid R35 000 on the day of negotiations and the balance was payable at an agreed future date. ${ }^{45}$ The parties signed an agreement in this regard. ${ }^{46}$ After the negotiations, the deceased entered dressed in special attire. At the same time, two of the deceased's aunts emerged carrying a matching attire for the respondent. They requested her to come with them to the bedroom where they presented her with the attire, informing her that it was her wedding dress. ${ }^{47}$ She changed into this dress and then she joined everyone. According to the respondent, it was at this stage that she noticed that her attire matched that of the deceased. ${ }^{48}$ She was then introduced to those present as the deceased's customary law wife. ${ }^{49}$ A celebratory mode ensued with the appellant welcoming the respondent as his daughter-inlaw, with the congratulatory words of those who were present - "finally!" finally!"50 The celebration was capture on video. ${ }^{51}$

In 2018, the relationship between the deceased and the respondent had broken down due to the deceased's infidelity and drug addiction. ${ }^{52}$ This culminated in the respondent leaving the common home. ${ }^{53}$ Any attempts at reconciliation were fruitless and the final result was the deceased committed suicide on 23 October 2018. ${ }^{54}$ Following the death, the respondent went back to the common home to mourn the deceased. The appellant ejected the respondent and changed locks to the common home. He told her that he did not recognise her as the wife of the deceased. ${ }^{55}$ These events triggered an urgent application in the South Gauteng Johannesburg Division (court a quo) for an order, amongst others, declaring that a customary marriage between her and the deceased existed. ${ }^{56}$ The appellant opposed the granting of the order on the ground that the marriage process had not been finalised and the

42 Sengadiv Tsambo supra, para 4.

43 Sengadi $v$ Tsambo supra, para 5.

44 Sengadi $v$ Tsambo supra, para 5.

45 Sengadi $v$ Tsambo supra, para 5.

46 Sengadi $v$ Tsambo supra, para 5.

47 Sengadi $v$ Tsambo supra, para 6.

48 Sengadi $v$ Tsambo supra, para 7.

49 Sengadi $v$ Tsambo supra, para 7

50 Tsambo $v$ Sengadi supra, para 8.

51 Tsambo $v$ Sengadi supra, para 8.

52 Sengadi $v$ Tsambo supra, para 11

53 Sengadi $v$ Tsambo supra, para 11.

54 Sengadi $v$ Tsambo supra, para 11.

55 Sengadi $v$ Tsambo supra, para 11.

56 Sengadi $v$ Tsambo supra, para 1. 
respondent had never been handed over to the deceased's family. ${ }^{57}$ The court a quo held that the events of the 26th of February 2016 constituted a customary marriage. It also held that the physical delivery of the bride had been dispensed with as the parties had preferred a "symbolic handing over". 58 The court also held that the practice of the handing over of the bride is unconstitutional insofar as non-compliance invalidates a customary marriage. ${ }^{59}$ On appeal by the deceased's father, the SCA held that it was not necessary for the court a quo to declare the practice of the handing over unconstitutional as none of the parties had argued this. ${ }^{60}$ Nonetheless, the SCA confirmed that there was a valid customary marriage and that the physical handing over of the bride is optional and that the parties could waive it in favour of a symbolic handing over. ${ }^{61}$

\section{A brief summary of the decisions}

The decisions above may be summarised as follow. In Moropane $v$ Southon, the SCA found that the practice of the handing over of the bride is a crucial stage of a customary marriage; in the absence of the handing over, there can never be a valid customary marriage. It also held that a customary marriage is rich in practices and customs, some of these may be summarised or waived. However, the handing over of the bride is cannot be summarised or waived. It must be stated that in Moropane $v$ Southon, the bride had been duly handed over to the groom's family.

In Mbungela $v$ Mkabi, the SCA was faced with a similar issue, save that in the latter decision, the bride had not been handed over. Instead, she remained in her home and followed later on her own. The SCA held the handing over of the bride was a flexible practice which the parties could waive. It also held that based on the evidence before the court, the parties and the families' intention was to waive the handing over of the bride. In Tsambo $v$ Sengadi, the SCA followed Mbungela $v$ Mkabi. In the former decision, the court added that the parties could opt for a symbolic handing over of the bride. It must be noted that Moropane $v$ Southon was also not rejected in both cases.

The present situation is that all the cases above are binding. In essence, the lower court may follow whichever decision. If one studies the pattern of subsequent decisions, they lend themselves to forum shopping. Subsequence decisions from the High Court have gone either way. ${ }^{62}$ Such a situation cannot be sustained.

57 Sengadi $v$ Tsambo supra, para 16.

58 Sengadi $v$ Tsambo supra, para 21.

59 Sengadi $v$ Tsambo supra, para 35.

60 Tsambo $v$ Sengadi supra, para 33.

61 Tsambo $v$ Sengadi supra, para 31.

62 In Mlamla $v$ Rubushe supra, para 22-23 the Mthatha followed the reasoning in Moropane $v$ Southon and rejected Mbungela $v$ Mkabi and Miya $v$ Mnqayane supra, followed Mbungela $v$ Mkabi and Tsambo $v$ Sengadi. 
The decisions above raise the following issues. Whether the handing over of the bride maybe waived in customary marriages? Does living customary law recognise the waiver of this custom? What is a symbolic handing over of the bride? Is the intention of the parties a determinant factor in customary marriages? The issue of terminology is a common thread in these cases. It should also be addressed. Noting that "umakoti" is a generic term that could mean married or engaged. ${ }^{63}$

\section{Living customary law and the handing over of the bride in customary marriages?}

\section{General}

As noted above, the requirements for a customary marriage appear in s 3(1) of the Recognition Act. The prospective spouses must: (a) both be above 18 years of age, (b) consent to be married to each other under customary law, and (c) the marriage must be negotiated and entered into or celebrated in accordance with customary law. It is accepted that whether the handing over of the bride is a requirement of a customary marriage lies in the requirements in (c). The purpose of this provision was to give way to living customary law. Therefore, the real question is whether the living customary law of any ethnic group recognises that the handing over may be summarised or waived. In this regard, the courts are required to ascertain the ethnic group to which the parties belong and the ascertainment of customary law. It is submitted that the lex loci domicile should prevail. ${ }^{64}$

\section{Ascertainment of customary law}

In Shilubana $v$ Nwamitwa, ${ }^{65}$ the Constitutional Court made the following statement:

To sum up: where there is a dispute over the legal position under customary law, a court must consider both the traditions and the present practice of the community. If development happens within the community, the court must strive to recognise and give effect to that development, to the extent consistent with adequately upholding the protection of rights. In addition, the imperative of section 39(2) must be acted on when necessary, and deference should be paid to the development by a customary community of its own laws and customs where this is possible, consistent with the continuing effective operation of the law...66

63 See Dladla, Hiner, Qwana and Lurie "Speaking to rural women: The sexual partnerships of rural South African women whose partners are migrants" 2001 Society in Transition 7980.

64 Sibisi "Is the requirement of the integration of the bride optional in customary marriages" 2020 De Jure 90102.

65 Shilubana v Nwamitwa 2008 (9) BCLR 914 (CC); 2008 (2) SA 66 (CC).

66 Shilubana $v$ Nwamitwa supra, para 49. 
The Law of Evidence Amendment Act ${ }^{67}$ (hereinafter LEAA) provides for two ways of ascertaining living customary law. S 1(1) of LEAA provides that "any court may take judicial notice of the law of a foreign state and indigenous law in so far as such law can be ascertained readily and with sufficient certainty...". Should the court not be able to take judicial notice of the law, s 1(2) of LEAA applies. In terms of this provision, a party must be allowed to adduce evidence in order to prove the existence of a legal rule. ${ }^{68}$ It is doubtful whether the whole of LEAA is still applicable in light of the constitutional restoration of customary law to its rightful place in South Africa. ${ }^{69}$

The wording of s 1(1) of LEAA suggests that the court has discretion on whether to take judicial notice or to call for evidence. ${ }^{70}$ This discretion must be exercised judiciously. ${ }^{71}$ A court may take judicial notice of a customary practice embodied in case law. ${ }^{72}$ A court may also take judicial notice of a practice embodied in statute. However, our statutes on customary law do not codify practices; a good example is s 3(1)(b) of the Recognition Act, which simply provides that a customary marriage must be negotiated and entered into or celebrated in accordance with customary law. Badejogbin submits that a court is not confined to decisions of higher courts; it may also take judicial notice of decisions of traditional courts. ${ }^{73}$ The author submits that taking judicial notice of decisions of traditional courts may prove beneficial, as the latter makes decisions based on lived reality. ${ }^{74}$

It is hereby submitted that while taking judicial notice of living customary law may prove convenient and save the court's time; however, when the practice is not an accurate reflection of the living customary law that is currently observed or is outdated, judicial notice may lead to ossification and distortion of customary law. ${ }^{75}$ Courts should not rely on official law for too long as this closes the door on living law. ${ }^{76}$ The fact that the parties are in dispute about a particular practice is a sufficient indication that the court cannot blindly take judicial notice of customary law. ${ }^{77}$ It is submitted that this is a good point in time to call

67 Law of Evidence Amendment Act 45 of 1988.

68 Bekker and Van der Merwe "Proof and Ascertainment of Customary Law" 2011 SAPL 115118.

69 Bekker and Van der Merwe 115.

70 Badejogbin 17.

71 Badejogbin 8.

72 Badejogbin 17-18.

73 Badejogbin 19.

74 Badejogbin 19.

75 See Osman "The Consequences of the Statutory Regulation of Customary Law: An Examination of the South African Customary Law of Succession and Marriage" 2019 PER/PELJ 1-2 on ossification and distortion of customary law.

76 Badejogbin 21.

77 See Hlophe $v$ Mahlalela 1998 (1) SA 449 (T) 457 and Mabena $v$ Letsoalo 1998 (2) SA 1068 (T) $1075 \mathrm{~A}$, to the effect that a court may take judicial notice if there is not dispute regarding the law. By analogy, should there be a dispute, a court must call for evidence. 
for evidence to assist the court in ascertaining living customary law. A party who has evidence to prove the existence of a rule must be allowed to do so. ${ }^{78}$ It is also submitted that a costs order may minimise frivolous litigation and the calling of witnesses when it is unnecessary to do so. Once the law has been ascertained, the court must apply it. If the application yields an injustice in violation of the Bill of Rights, the court should develop such a practice in accordance with s 39(2) of the Bill of Rights. ${ }^{79}$

In Moropane $v$ Southon, there was no dispute on the question of the handing over of the bride. The dispute was on whether ilobolo had been negotiated. However, in Mbungela $v$ Mkabi and Tsambo $v$ Sengadi, there was a dispute on the handing over of the bride. It must be added that in Tsambo $v$ Sengadi, there was no dispute in the court a quo on whether the handing over of the bride was a requirement. The dispute surfaced for the first time in the SCA. ${ }^{80}$ Ironically, the SCA raised the issue with the appellant's failure to dispute certain allegations of facts in the court $a$ quo. ${ }^{81}$

In Mbungela $v$ Mkabi and Tsambo $v$ Sengadi, the SCA did not take judicial notice of living law nor did it call for evidence. Instead, it held that the custom of the handing over of the bride has evolved. ${ }^{82}$ It is argued that without ascertaining this, the SCA was not in a position to make this determination. Admittedly, since the SCA is an appeal court, issues relating to evidence ought to have been ironed out in the courts a quo. However, this was not done in the court a quo. Therefore, the SCA could have stepped in and called for evidence. This move is not unprecedented as the Constitutional Court did call for evidence in $M M v M N .{ }^{83}$

\section{The handing over of the bride, waiver, and symbolic handing over}

It has been pointed out that the real question is whether customary law and living customary law, in particular, recognises that the handing over of the bride may be summarised, waived, or dispensed with. This question can only be answered if one considers the significance of the handing over of the bride in customary marriages.

The handing over of the bride to the groom's family is a common feature in customary marriages. In addition to payment of ilobolo (at least partial payment), the bride must be integrated into her new family.

79 Sibisi "Breach of promise to marry under customary law" 2019 Obiter 347.

80 Tsambo $v$ Sengadi (SCA) supra, para 12.

81 Tsambo $v$ Sengadi (SCA) supra, paras 19-21.

82 Tsambo $v$ Sengadi supra, para 17.

83 MMvMN 2013 (4) SA 415 (CC). 
Integration of the bride takes place at the groom's home. ${ }^{84}$ On this occasion, the bride is handed over to her new family. In Zulu customary marriages, the bride also gives her in-laws gifts. ${ }^{85}$ She is also introduced to the ancestors by smearing her feet with gall. ${ }^{86}$ The integration of the bride comprises many events; ${ }^{87}$ these events include ukumekeza (Swati), utsiki (Xhosa), ukugqiba amasondo (Zulu), and the handing over of the bride. Some of these events are optional. However, the handing over of the bride is not. ${ }^{88}$ In other words, the handing over of the bride is an essential aspect of the integration of the bride, and as Bekker puts it: "It is not the essential requirements that can be waived but rather the rituals associated with the essential requirements". 89 As already pointed out above, the SCA ignored this and in the process ignored living law.

The answer to the question of whether the handing over of the bride could be summarised or waived lies in customary law. Accordingly, the handing over of the bride is an essential requirement that cannot be dispensed with. However, it is open for a person who alleges that living law has devolved to adduce evidence in proof. ${ }^{90}$ No evidence of this nature was adduced in Mbungela $v$ Mkabi and Tsambo $v$ Sengadi. Therefore, it is submitted that in these decisions, the SCA was not in a position to make the decision which it made.

In the absence of any proof of deviation, the correct legal position is that the handing over of the bride is a crucial stage of a customary marriage. Without this, the bride cannot be integrated into her new family. The handing over of the bride need not be a major celebration, it may be summarised by limiting the number of people that accompany the bride to her new family. This being said; is it possible for the parties to opt for a symbolic handing over or the so-called "declared acceptance"? ${ }^{91}$ Precedence for a "symbolic handing over" is found in the decision of the court a quo in Tsambo $v$ Sengadi. It is unclear what constitutes a symbolic handing over. Whether it is based on the parties' intentions or out of the need to expedite a customary marriage is a

84 Bekker "Integration of the Bride as a requirement for a Valid Customary Marriage: Mkabe Minister of Home Affairs [2016] ZAGPPHC 460" 2018 PER/ PELJ 111 and Sibisi 91.

85 This practice is not unique to the Zulus. Other South African ethnic groups (if not all) have similar practices.

86 Nel The Ancestors and Zulu Family Transitions: A Bowen Theory and Practical Theological Interpretation (PhD dissertation 2007 UNISA) 167.

$87 N D$ v MM supra, para 17. For an example of events that comprise a Swati customary marriage, see para 19 of the judgment cited herein. It is interesting to note that ukumekeza is not mentioned. However, this may be explained by the fact that in Mabuza v Mbatha (2003 (4) SA 218 (C), while the parties were Swati, they were South African Swatis. In the former judgment, the applicable law was that of the Kingdom of eSwatini. Another explanation may be that ukumekeza is an old practice, which is no longer followed to the core as it may have been back then.

88 Moropane $v$ Southon supra; Bekker 1 and Sibisi 91.

89 Bekker 10.

90 Bekker 11.

91 Tsambo $v$ Sengadi supra, para 26 
matter of speculation. Perhaps a plausible explanation is the fact that a symbolic handing over is unique to parties who decide to cohabit. Can it be said that the resumption of cohabitation after the ilobolo negotiations amounts to a symbolic handing over? Does pre-marital cohabitation have any bearing on the requirements for a customary marriage? These are rather difficult questions - more so taking into account that the concept of a symbolic delivery is a recent introduction.

The SCA preferred a "declared acceptance" in Tsambo $v$ Sengadi. 92 This relates to the conduct of the appellant on the day of the ilobolo negotiations where it is alleged that he introduced the respondent as the wife of the deceased. As the appellant had not provided a version, the court accepted the respondent's version of the events that transpired. As has been noted above, the appellant's attempts to dispute facts on appeal were, ironically, rejected by the court. The court, therefore, accepted that the appellant had embraced the respondent - thus welcoming her into his family. This was, according to the court, a declaration of acceptance of the respondent as his daughter-in-law, in compliance with the "flexible" requirement of the handing over.

\section{Intention of the parties}

To what extend should the courts focus on the intention of the parties regarding the marriage? In Mabuza $v$ Mbatha, ${ }^{93}$ Mbungela $v$ Mkabi and Ngema $v$ Dabengwa, ${ }^{94}$ the courts did focus on the intention of the parties. Interestingly, in the latter judgment, the court upheld the handing over of the bride as an indispensable requirement. ${ }^{95}$ In Tsambo $v$ Sengadi, the respondent and the deceased were depicted as people who believed in observing traditions. ${ }^{96}$ The court attached credence to this. However, they were depicted as progressive as opposed to being conservative. The court concluded that while the parties wanted to observe traditions, they intended to expedite matters. ${ }^{97}$

It is submitted that the court was selective in its approach. When ilobolo was negotiated and partially paid, the parties expressly agreed that they would meet again and pay the remaining R10 000. This indicates that the parties did not intend to finalise anything on the day of the negotiations. Although ilobolo does not have to be paid in full before a customary marriage, had the parties intended that the R10 000 would be paid after the marriage, they would have stated so. The court should not have attached anything to the deceased's presence at the respondent's residence. He was not a party to the negotiations (no rule says he cannot negotiate); furthermore, it is common for the groom to be

92 Tsambo $v$ Sengadi supra, para 26.

93 Mabuza $v$ Mbatha supra, see paras 1 and 19-21.

94 Ngema $v$ Dabengwa unreported case number 2011/3726 SGJ (15 June 2016).

95 Ngema $v$ Debengwa supra, para 23-26.

96 Tsambo $v$ Sengadi (SCA) supra, para 3.

97 Tsambo v Sengadi (SCA) supra, para 24 
somewhere in the vicinity while the negotiations proceed - so that he may be consulted if need be.

In addition, one acknowledges that registration is not a sine qua non (condition without which) for a valid customary marriage. ${ }^{98}$ However, the reason that the legislature included the provision in the Recognition Act that non-registration of a customary marriage does not affect its validity was to accommodate the largely elderly, illiterate, and poor people on whom the Recognition Act impacted. ${ }^{99}$ The parties had been to university (the author is not aware whether they graduated). The deceased had a successful music career (the author is not aware of the respondent's career). ${ }^{100}$ It was much easier for the parties to register this marriage. They did not do this. The court ought to have considered this as well. 101

\section{Terminology and celebrations in customary Law}

The purpose of this part of the article is to clarify terminology and the significance of celebrations in customary law. In Tsambo $v$ Sengadi, the SCA seems to have attached credence to the respondent having been introduced as the "wife" of the deceased. ${ }^{102}$ Under customary law, the concept of "wife" (mosadi or makoti) does not necessarily mean married. It may be used to denote that a person is more than just a girlfriend, that is, a fiancé. For instance, in isizulu, a concept for a fiancé exists; a fiancé is ingoduso. However, it is hardly used. Instead, umakoti is a popular concept. In addition, in relation to a woman, it may be said that she is ganile or uganile, meaning that she is a fiancé. ${ }^{103}$ The concept (u)ganile also means married.

Like in any other culture or tradition, a milestone achievement is celebrated. When a man pays ilobolo, it is usually an indication that he is preparing to get married. When a young man does the same, it has more significance. It means he is growing out of his youthfulness and is

98 S 4(9) of the Recognition Act.

99 Manthwa 444.

100 Tsambo $v$ Sengadi (SCA) supra, para 24.

101 In $N D v M M$ supra, para 10 , the court stated that having a marriage registered is advantageous. This ensures that a marriage certificate is issued and operates as prima facie proof of a customary marriage. In the absence of this certificate, a party who alleges will have trouble in proving this. It is therefore doubtful that the respondent and the deceased in Tsambo $v$ Sengadi supra, being people who were exposed to advantages, would have deliberately failed to register their alleged marriage - unless they did not intend the event in question to be a wedding.

102 Tsambo $v$ Sengadi (SCA) supra, paras 5, 26.

103 Nkosi and Van der Niekerk "The unpredictable judicial interpretation of section 3(1)(b) of the Recognition of Customary Marriages Act 120 of 1998 Eunice Xoliswa Ngema v Sifiso Reymond Debengwa (2011/3726) [2016] ZAGPJHC 163 (15 June 2016)”2018 (18) THRHR 345 350, 353. 
stepping into manhood. This calls for a celebration. Therefore, the fact that a celebration ensues after the ilobolo negotiation does not make an event a marriage.

Like any other marriage, a customary marriage is celebrated. This celebration must be in accordance with customary law. The marriage does not only unify the parties, it also unifies the families as well as ancestors of the respective families. ${ }^{104}$ This necessitates the need to conduct ceremonies at both the bride's and the groom's family - thus indicating that the bride is about to leave her maiden family to join another family. Thereafter, she must be handed over to her in-laws who will conduct a ceremony to welcome her. ${ }^{105}$ This ceremony integrates her into her new family. The bride also hands over gifts to her in-laws. This as well as an occasion to celebrate.

It is submitted that in Tsambo $v$ Sengadi, the celebration was a mere celebration of the payment of ilobolo - a milestone achievement in a young couple's relationship. Furthermore, these celebrations occurred at the bride's home. While it is accepted that customary law is flexible and that practices change to adapt to the needs of the community, and to borrow from Hlophe JP in Mabuza $v$ Mbatha "... it is probably practiced differently than it was centuries ago", 106 practices do not change overnight and some practices are not as flexible. To illustrate, it was unacceptable for a woman to pay ilobolo for herself centuries ago. This is still the case centuries later. The same applies to cohabitation. ${ }^{107}$

The question that the court $a$ quo and the SCA did not ask in Tsambo $v$ Sengadi is if the practices of the community to which the litigants belonged were so flexible that it allowed a head of the family to welcome the bride of his family at her maiden home. In other words, can a man summon his ancestors at another man's homestead? As absurd as this sounds, the court could have nonetheless verified it by ascertaining the living law. This was done in Mabuza $v$ Mbatha. As submitted above, this did not happen in Tsambo $v$ Sengadi. Therefore, it is submitted that a declared acceptance is not consistent with African culture.

\section{The creation of uncertainty}

The last argument is that Tsambo $v$ Sengadi raises the question of legal certainty. The reader is reminded that the SCA is the second-highest court in the land and its binds all courts. The current precedence allows lower courts to choose between either Moropane $v$ Southon and Mbungela $v$ Mkabi, and Tsambo $v$ Sengadi. As pointed out above, subsequent

104 Van Niekerk "The courts revisit polygyny and the Recognition of Customary Marriages Act 120 of 1998" 2013 SAPL 469 and Mwambene 51.

105 Nel 167.

106 Mabuza v Mbatha supra, para 25.

107 Bekker and Coertze Seymour's Customary Law in Southern Africa (4th ed) (1982) 150 
decisions have gone either way. Admittedly, and without suggesting that Moropane $v$ Southon is not supported by any other decision, which it is, the scale is tipping in favour of the line of decisions that view the handing over of the bride as a flexible requirement, which parties may waive. These decisions yield to legal uncertainty and may not sit comfortably with the law observed. The result may be paper law of very little significance. ${ }^{108}$ The only thing that may be achieved is a lack of confidence in the competence of the judiciary to deal accurately and decisively with customary law. ${ }^{109}$

If the handing over of the wife is a flexible requirement that parties may waive, what then are the requirements for a valid customary marriage? The decisions above create the impression that, provided that the parties are aged 18 or above and consent to be married in terms of customary law, mere negotiation of ilobolo finalises a customary marriage. This flies in the face of a string of decisions to the effect that mere finalisation of ilobolo negotiations does not conclude a customary marriage. ${ }^{110}$ Perhaps this should be a starting point to adjudicating customary marriages. Courts should ask if, in addition to negotiation and payment of ilobolo, any other practices were conducted after the payment of ilobolo. In the absence thereof, there can never be a customary marriage. ${ }^{111}$

If not the handing over, then what? What is it, over and above the negotiation of ilobolo, that makes a marriage truly customary? It is submitted that the court cannot, without ascertaining the living content of customary law through judicial notice or calling evidence, provide answers to these questions. Thus, regard must be given to the ascertainment of living customary law. It seems like the courts pay too much attention to the idea that customary law does not remain static. While this is correct, it must also be noted that it does not change overnight, and courts should not relent in their mandate to ascertain living customary law. Failure to do this is tantamount to giving credence to the idea that customary law is confusing.

It is observed that cohabitation plays a role in influencing the decisions of courts. Payment of ilobolo following cohabitation seems to strengthen the idea of a symbolic handing over. ${ }^{12}$ In Sengadi $v$ Tsambo, the court considered this. The court seems to drive the narrative that cohabitation

108 Dlamini "Should ilobolo be abolished? A reply to Hlophe" 1985 CILSA $361368-370$ and 46.

109 Manthwa "Towards a new form of customary marriage and ignorance of precedence" 2021 TSAR 200.

110 These judgments include Fanti v Boto 2008 (5) SA 405 (C); Ndlovu $v$ Mokoena 2009 (5) SA 400 (GNP) and Motsoatsoa $v$ Roro supra.

111 Maithufi "The requirements for validity and proprietary consequences of monogamous and polygynous customary marriages in South Africa: Some observations" 2015 De Jure 261266.

112 Mbungela $v$ Mkabi supra, para 25 and Tsambo $v$ Sengadi supra, para 27. 
renders the need to hand over the bride to her new family redundant. ${ }^{113}$ Adults who desire to live together should be able to do so without there being any consequences other than those they expressly agree upon; ${ }^{114}$ in the words of De Villiers AJ in $N D v M M$ "There must be a factual distinction between a cohabitation arrangement, and a customary marriage." 115 And to borrow from Jolwana J in Mlamla $v$ Rubushe:

I disagree, with respect, with the authorities cited in the applicant's heads of argument to the effect that two individuals deciding to live together on their own after lobola was paid can be said to constitute constructive delivery if they live together with the knowledge of the bride's family. The fact that the two individuals lived together publicly may found some other claim. However, it cannot be the basis for the conclusion that a valid customary law was concluded, merely based on lobola having been paid. ${ }^{116}$

Should this not be the case, the legislature ought to clarify.

\section{Conclusion}

The current state of judicial precedent on the requirements of the handing over of the bride to the family of the groom is uncertain. This uncertainly emanates from the SCA. The SCA, being the second-highest court in the land, has not articulated itself with sufficient clarity on the matter of the handing over of the bride. Although the latter decisions of the SCA purport to be in accordance with living customary law, in essence, they are not a correct reflection on living customary as neither of these decisions have ascertained the handing over of the bride under living customary law. This article has made it clear that a court may take judicial notice of a custom. If a deviation has been alleged, the court must call for evidence to verify this deviation. Precedent indicated that the handing over of the bride is a crucial aspect of a customary marriage. Without the handing over, there can never be a valid customary marriage. However, in Mbungela $v$ Mkabi and Tsambo $v$ Sengadi, the SCA alleged a deviation but did not ascertain living law. This is despite its earlier decision to the contrary in Moropane $v$ Southon, which it ought to have followed.

It is submitted that should the occasion arise again, the SCA or any lower court should follow Moropane $v$ Southon as this decision is wellrooted in precedence which the court can easily take judicial notice of. In the event of any deviation being alleged, the proper step is to call for evidence to establish whether the physical handing over of the bride may be waived. It is doubtful whether the handing over of the bride may be waived completely. Should this be the case, the consequence will be that

113 Osman "Precedent, waiver and the constitutional analysis of handing over the bride [Discussion of Sengadiv Tsambo 2018 JDR 2151 (GJ)] 2020 SLR 80 84.

114 Tsambo $v$ Sengadi supra, para 17.

$115 N D v M M$ supra, para 41

116 Mlamla $v$ Rubushe supra, para 18. 
mere finalisation of ilobolo negotiations concludes a customary marriage. This is not on par with well-established precedence. However, the event of the handing over of the bride may be summarised. 